\title{
D/H FRACTIONATION OF COEXISTING BIOTITE AND HORNBLENDE IN SOME GRANITIC ROCK MASSES
}

\author{
Yoshimasu Kuroda*, Tetsuro Suzuoki**, Sadao Matsuo***, and \\ SATOSHI KANISAWA****
}

\begin{abstract}
The deuterium content $\left(8 \mathrm{D}_{\mathrm{SM}}\right.$ w) of the water extracted from coexisting biotite and hornblende in granitic rocks was measured. The relationship between $\delta \mathrm{D}$ of biotite and hornblende suggested an isotopic equilibrium in the rocks of four granitic bodies in the Kitakami mountains (Northeast Japan), and the maximum temperature of isotopic equilibration of biotite and hornblende was estimated to be $700-1,000^{\circ} \mathrm{C}$, provided that the minimum temperature was $450-550^{\circ} \mathrm{C}$. The $\delta \mathrm{D}$. value obtained for the water with which these minerals equilibrated was $-29 \sim-37 \%_{0}$ and is definitely enriched in deuterium relative to the present local surface water.

On the other hand, the relationsmp petween $\delta \mathrm{D}$ of biotite and hornblende in the Ryoke metamorphic belt contiguous to the Median Dislocation Line (Southwest Japan) indicated an isotopic disequilibrium. In this case a complicated history of formation of these granitic rocks in terms of the interaction of water and hydrous silicates was inferred.
\end{abstract}

\section{INTRODUCTION}

Friedman and Smith (1958) first measured the deuterium content $(\delta \mathrm{D})$ of the water in coexisting obsidian and perlite and found that there seemed to be no close correlationship between their $\delta \mathrm{D}$ values. They also found that $\delta \mathrm{D}$ of perlite was some $40 \%$ lower than that of the local surface water. Later, Godfrey (1962) and Taylor and Epstein (1966) measured $\delta \mathrm{D}$ of water in pairs of natural hydrous silicates, and estimated the fractionation factor $(\alpha)$ to be 1.009-1.053 in the muscovite-hornblende pair. According to their results, deuterium is most enriched in muscovite among these minerals. Shieh and Taylor (1969) and Forester and Taylor (personal communication) extended the scope. Sheppard et al. (1969), Savin and Epstein (1970) and Lawrence $(1970)$ also estimated the fractiona- tion factors of deuterium between water and hydrous silicates including clay minerals.

Suzuoki and Epstein (1970), (1972) first conducted an experimental determination of $\alpha$ between water and various hydrous minerals under hydrothermal conditions, and found that $\delta \mathrm{D}$ of the hydrogen in the lattice of the mineral is controlled by the composition of the cations in the octahedral position of minerals, as well as the temperature of equilibration and $\delta \mathrm{D}$ of the coexisting water. On this basis, Suzuoki and Epstein (personal communication) have already made some applications to the pairs of natural hydrous silicates.

Origin of the hydrogen included in the lattice of hydrous minerals and of the water of the fluid inclusion of various minerals is one of the most important problems in petrology. This problem is related to the

(Manuscript received, November, 12, 1973)

* Department of Geology, Shinshu University, Matsumoto

** Meteorological College, Kaskizwa

*** Depariment of Chemistry, Tokyo Institute of Technology, O-okayama, Tokyo

**** Department of Earth Sciences, College of Anis and Sciences, Tohoku University, Sendai 
question of the presence or non-presence of the juvenile water in the mantle, and to the isotopic composition of crustal water as a function of region and depth. Sheppard and Epstein (1970) measured $\delta \mathrm{D}$ of phlogopites from various kimberlites and estimated $\delta \mathrm{D}$ of "juvenile water" to be $-48 \pm$ $20 \%$. In this paper we deal with biotitehornblende pairs in granites in order to confirm the chemistry and temperature dependence of hydrogen isotope ratios in natural systerns and further to estimate $\delta \mathrm{D}$ of the water present in granite magmas.

\section{SAMPle Description}

The biotite-hornblende pairs were taken from four granitic bodies, viz, the Hitokabe mass, the Kesengawa mass, the Tono mass, and the Hirota mass in the

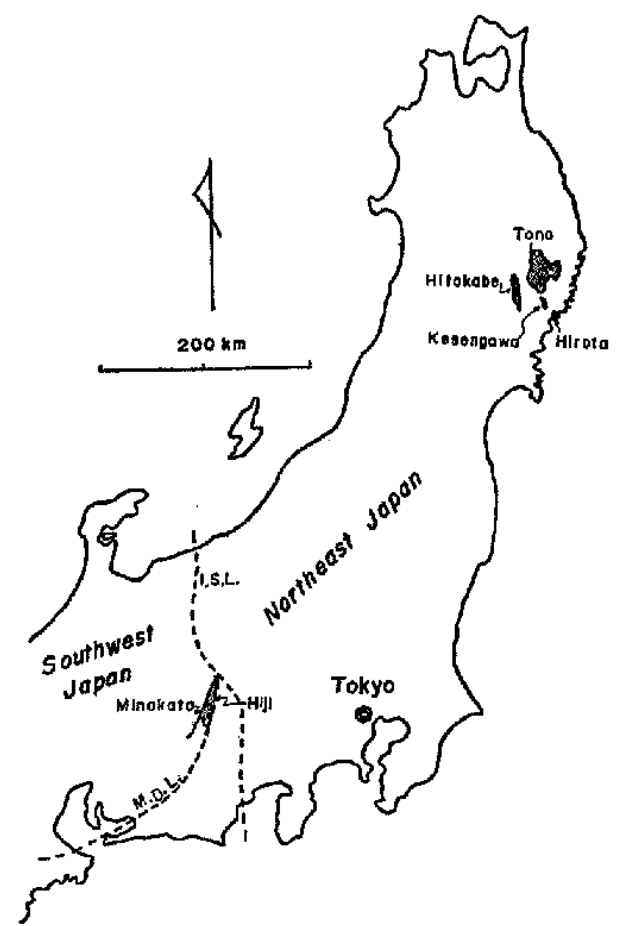

Fig. 1. Locality of the granitic masses investigated.

M.D.L. : Median Dislocation Line, I.S.L.: Itoigawa-Shizuoka Line.
Kitakami mountains, the Northeast Japan, and from two bodies, i.e., the Hiji mass and the Minakata mass, in the Ryoke metamorphic belt, the Southwest Japan. The localities of these granitic bodies are shown in Fig, 1.

The four bodies in the Kitakami mountains were intruded during the Cretaceous period and have given contact metamorphism to the enclosing Paleozoic and Mesozoic formations. According to Kawano and Ueda (1965), K-Ar ages of biotites from these bodies are 110-120 m.y. The Hitokabe mass (Kanisawa, 1969), $\mathrm{SiO}_{2}$ content of which ranges from 61 to $68 \%$, consists of homblende-biotite granodiorite and hornblende-biotite quartz diorite. In this mass, dark inclusions of quartz diorite with $\mathrm{SiO}_{2}$ content of about $56 \%$ are plentiful. The Tono mass, the $\mathrm{SiO}_{2}$ content of which varies from 56 to $70 \%$, the largest granitic mass in the Northeast Japan, is composed of biotite-granodiorite, biotite-hornblende granodiorite and homblende-biotite quartz diorite, sometimes containing clinopyroxene. The Kesengawa mass, the $\mathrm{SiO}_{2}$ content of which ranges from 57 to $65 \%$, consists of biotite-homblende granodiorite and biotitehornblende quartz diorite, sometimes containing clinopyroxene. The Hirota mass, the $\mathrm{SiO}_{2}$ content of which is rather uniform in the range from 61 to $63 \%$, is small in scale and composed of clinopyroxene-biotite-homblende granodiorite. This mass seems to be formed under shallower condition than the other three.

The chemistry of biotite and homblende in these masses is typical of these minerals in granite as already described by Kanisawa (1972). The $\mathrm{Fe} /(\mathrm{Fe}+\mathrm{Mg})$ ratios of biotite and hornblende are $0.35-0.52$ and $0.34-0.46$ respectively. $\mathrm{K}_{\mathrm{D}}(\mathrm{Mg} / \mathrm{Fe})_{\text {biot/horab }}$ is $0.64-0.81$, and the numbers of $\mathrm{Al}^{\mathrm{IV}}$ of 
biotites and hornblendes in the formula calculated on the basis of $24(\mathrm{O}, \mathrm{OH})$ are $2.13-2.49$ and $0.72-1.30$ respectively.

The Hiji and Minakata masses belong to the Older Ryôke granitic rocks. The Hiji mass the absolute age of which has been determined to be 95 and $110 \mathrm{~m}$.y. by $\mathrm{Pb}-\alpha$ studies of zircon (Karakida et al., 1965), and 83 m.y. by Rb-Sr of biotite (Hayase, 1967), is slightly younger than the Minakata. Both seem to be protoclastic intrusions the origin of which had some relation to the activity of the Median Dislocation Line. The $\mathrm{SiO}_{2}$ content is lower in the Hiji mass, $60-64 \%$, than the Minakata mass, $67-70 \%$. The chemistry of biotite and homblende is rather peculiar in that both minerals have high iron-magnesium ratios, $\mathrm{Fe} /(\mathrm{Fe}+\mathrm{Mg})$, of $0.51-0.76$ in biotite and $0.48-0.76$ in hom- blende. The reason for the high $\mathrm{Fe} / \mathrm{Fe}+$ $\mathrm{Mg}$ ) ratios of the minerals in these masses compared to that of the masses in Kitakami is not clear. It is interesting, however, to note that biotite-hornblende pairs from these rocks exibit an apparent disequilibrium with respect to the behavior of hydrogen isotopes as described later.

\section{EXPERIMENTAL}

Mineral separations were carried out using magnetic and heavy liquid methods, after pulverizing the samples to 100 meshsize. The purity of separates was higher than $98 \%$, except for the biotites of $\mathrm{HJ}-2$ and MN-1, where the separation of chlorite was impossible (see Table 1).

The extraction of water from hydrous silicates such as biotite and hornblende was

Table 1. Analytical results and pertinent chemical information.

\begin{tabular}{|c|c|c|c|c|c|c|c|c|c|}
\hline \multirow[b]{2}{*}{ No. } & \multirow{2}{*}{$\begin{array}{l}\mathrm{SiO}_{2} \\
\text { host } \\
\text { rock. } \\
\text { (wt. }\end{array}$} & \multicolumn{4}{|c|}{ biatite } & \multicolumn{3}{|c|}{ hornblende } & \multirow[b]{2}{*}{$\begin{array}{l}\text { RI VI (No. on } \\
\text { basis of } \\
\left(0,0 \text { OE }{ }_{24}\right)\end{array}$} \\
\hline & & $\begin{array}{l}\delta D\left(q_{0}\right) \\
\text { (SMOW) }\end{array}$ & $\begin{array}{c}\mathrm{B}_{2} \mathrm{O} \\
\text { (wt. z) }\end{array}$ & $\begin{array}{l}\text { Fe/ }(\mathrm{Fe}+\mathrm{Mg}) \\
\text { (atomic } \\
\text { frac.) }\end{array}$ & $\begin{array}{l}A 1^{V I} \text { (No, on } \\
\text { basis of } \\
\left.(0, O H)_{24}\right)\end{array}$ & $\begin{array}{l}S D\left\{z_{0}\right\} \\
\text { (SMOW) }\end{array}$ & $\begin{array}{c}\mathrm{H}_{2} \mathrm{O} \\
(w t, 8)\end{array}$ & $\begin{array}{l}\text { Fe/ (Fe+Mg) } \\
\text { (atomie } \\
\text { frac.) }\end{array}$ & \\
\hline HK-1* & $55.44 *$ & -78.3 & 3.66 & 0.51 & 0.292 & -69.2 & 2.06 & 0.45 & 0.246 \\
\hline $\mathbf{x x}-2 *$ & $55.58 *$ & -72.2 & 3.54 & 0.50 & $0.34 \mathrm{~B}$ & -68.4 & 2.04 & 0.43 & 0.186 \\
\hline HK-3 & 60.66 & -59.5 & 3.98 & 0.47 & 0.227 & -65.6 & 2.12 & 0.42 & 0.139 \\
\hline HK- 6 & 63.63 & -73.1 & 3.53 & 0.52 & 0.213 & -69.8 & 2.19 & 0.45 & 0.177 \\
\hline $\mathrm{HR}-9$ & 66.77 & -72.2 & 3.78 & 0.51 & 0.104 & -70.4 & 2.19 & 0.46 & 0.169 \\
\hline$K R-2$ & $61.56^{\circ}$ & -72.4 & 3.02 & 0.46 & 0.151 & -62.6 & 1.89 & 0.36 & 0.007 \\
\hline$H R-3$ & 62.77 & -73.9 & 3.22 & 0.46 & 0.000 & -63.2 & 2.11 & 0.36 & 0.056 \\
\hline HR 4 & 62.53 & -76.2 & 3.34 & 0.45 & 0.000 & -69.7 & 1.94 & 0.37 & 0.000 \\
\hline$T E-1$ & 56.52 & -65.6 & 3.34 & 0.51 & 0.265 & $-58,8$ & 1.92 & 0.42 & 0.193 \\
\hline $2 \pi-2$ & 62.34 & -80.0 & 3.96 & 0.43 & 0.000 & -69.2 & 2.07 & 0.34 & 0.084 \\
\hline$T N-3$ & 67.01 & -74.3 & 3.78 & 0.43 & 0.268 & & & & \\
\hline$T N=4$ & 70.35 & -73.9 & 3.90 & 0.35 & 0.055 & & & & \\
\hline RS-I & 57.11 & -58.7 & 3.78 & 0.48 & 0.184 & -52.4 & 2.00 & 0.38 & 0.183 \\
\hline $\mathrm{KS}-2$ & 64.97 & -63.7 & 4.06 & 0.44 & 0.000 & -58.7 & 2.03 & 0.36 & 0.109 \\
\hline HJ-1 & 62.86 & -67.1 & 4.13 & 0.51 & 0.297 & -67.7 & 2.15 & 0.52 & 0.365 \\
\hline $\mathrm{HI}-2$ & 64.13 & -64.0 & $5.33^{* *}$ & 0.55 & 0.035 & -70.4 & 2.37 & 0.53 & 0.107 \\
\hline $\mathrm{HJ}-3$ & 62.42 & $-78,2$ & 4.35 & 0.51 & 0.169 & -94.0 & 2.07 & 0.48 & 0.269 \\
\hline $\mathrm{EJ}-4$ & 59.95 & -85.7 & 4.85 & 0.55 & 0.088 & -102.0 & 1.92 & 0.54 & $0.2 \mathrm{Bg}$ \\
\hline $\mathbb{N}-1$ & 69.73 & -65.2 & $5.48 * *$ & 0.76 & 0.000 & -74.9 & 1.73 & 0.76 & 0.296 \\
\hline $\mathrm{MN}-2$ & 69.96 & -60.0 & 4.01 & 0.76 & 0.061 & -64.7 & 1.94 & 0.74 & 0.201 \\
\hline$M N-3$ & 66.98 & -86.1 & 3.86 & 0.62 & $0.2 \mathrm{BO}$ & -80.6 & 2.07 & 0.58 & 0.344 \\
\hline$M N-4$ & 68.00 & -76.8 & 4.33 & 0.69 & 0.074 & -78.2 & 1.97 & 0.69 & 0.373 \\
\hline
\end{tabular}

*: dark inclusions, **: probably containing some amounts of chlorite.

HK: Hitokabe, HR: Hirota, TN: Tono, ISS: Kesengawa, HJ: Hiji and MN: Minakata. 
performed by the dehydration technique using high frequency induction heating similar to that described by Friedman and Smith (1958) and Godfrey (1962). The dehydration vessel modified by Epstein and Taylor (1970) was used in this study. The pre-heated platinum crucible and the powdered sample were handled in a moisturefree chamber to protect completely the sample from possible contamination by extraneous water.

Usually, water vapor and hydrogen gas were evolved simultaneously in the dehydration process of mineral treated. Hydrogen gas was converted to water by heating it with $\mathrm{CuO}\left(500 \sim 600^{\circ} \mathrm{C}\right)$ which was trapped to enhace the quick pumping of evolved gases from the dehydration vessel. This procedure minimizes the glow-discharge during the induction heating. A heavy glowdischarge gives erratic results on $\delta \mathrm{D}$ measurement. The water extracted was passed over hot uranium metal $\left(700^{\circ} \mathrm{C}\right)$, and converted to molecular hydrogen (Bigeleisen et al., 1952). After measuring the volume of the evolved hydrogen the isotopic composition of the gas was determined using a specially constructed mass spectrometer.

The $\mathrm{D} / \mathrm{H}$ ratio is presented by the following expression,

$$
\begin{aligned}
\delta \mathrm{D}\left(\%_{0}\right) & =\frac{(\mathrm{D} / \mathrm{H})_{\text {sample }}-(\mathrm{D} / \mathrm{H})_{\text {sMow }}}{(\mathrm{D} / \mathrm{H})_{\text {sMow }}} \\
& \times 1,000
\end{aligned}
$$

where SMOW refers to Standard Mean Oceanic Water.

A repeated run of a laboratory-reference muscovite gave the standard deviation of $\pm 1.5 \%$ and $\pm 0.06 \%$ for $\delta \mathrm{D}$ and water content respectively.

\section{Results}

In Table 1 are listed $\delta \mathrm{D}$ values and

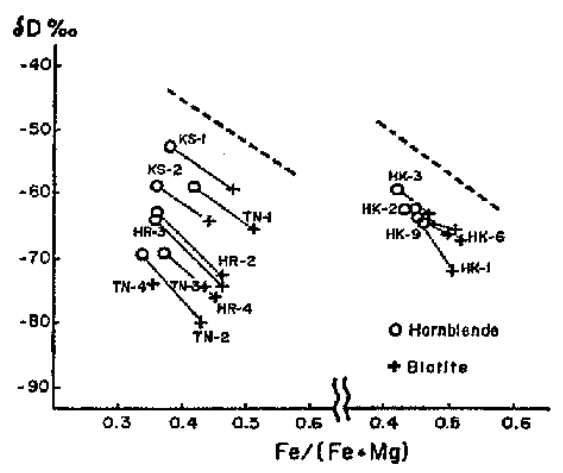

Fig. 2. Relationship between $\delta \mathrm{D}$ and $\mathrm{Fe} /(\mathrm{Fe}+\mathrm{Mg})$ of biotite and hornblende of the granitic masses in the Kitakami mountains. Notation in the figure is the same to that in Table 1 .

the yield of water extracted from biotite and hornblende together with pertinent chemical information. As shown in Fig. 2, the biotite-hormblende pairs from four granitic masses in Kitakami mountains seem to approach equilibrium with respect to deuterium partition, because the tie-lines between the coexisting biotite and hornblende on the $\delta \mathrm{D}$ versus $\mathrm{Fe} /(\mathrm{Fe}+\mathrm{Mg})$ diagram are nearly parallel to the "equilibrium line" (the broken kine in Fig. 2) that was experimentally determined by Suzuoki and Epstein (1970), (1972). The actual equilibrium line moves up and down on the diagram depending on the temperature of equilibration (or crystallization) and the value of $\delta \mathrm{D}$ of coexisting water. According to Suzuoki and Epstein (1970), (1972), the equilibrium partition of deuterium between biotite and homblende is almost even, provided that the $\mathrm{Fe} / \mathrm{Mg}$ ratios of minerals are the same. The equilibrium fractionation between biotite and hornblende can be regarded as being a function of the difference between their $\mathrm{Fe} / \mathrm{Mg}$ ratios.

On the pairs of the low temperature side such as TN-2, however, $8 \mathrm{D}$ value of 
biotite is slightly lower than the equilibrium line, provided that $\delta \mathrm{D}$ value of hornblende is just on the equilibrium line. In Fig. 2, the $\delta \mathrm{D}$ and $\mathrm{Fe} / \mathrm{Mg}$ data for coexisting biotite-hornblende pairs from the Hitokabe and Hirota masses show little scatter. Data for the Kesengawa and Tôno masses plot in different positions. The tie-lines of the Tono mass are widely separated. The tielines of coexisting biotite and hornblende from host rocks with less $\mathrm{SiO}_{2}$ content appear in the higher $\delta \mathrm{D}$ side of Fig. 2 . The exceptions are HK-1 $\left(\mathrm{SiO}_{\mathrm{g}}: 55.44 \%\right)$ and $\mathrm{HK}-2\left(\mathrm{SiO}_{2}: 55.58 \%\right)$ from the Hito-

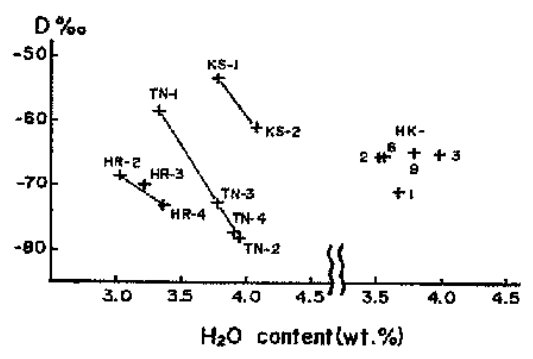

Fig. 3. Relationship between $\delta \mathrm{D}$ and $\mathrm{H}_{2} \mathrm{O}$ content of biotite of the granitic masses in the Kitakami mountains.

$\delta \mathrm{D}$ values are normalized to $\mathrm{Fe} /(\mathrm{Fe}+\mathrm{Mg})=0.40$.

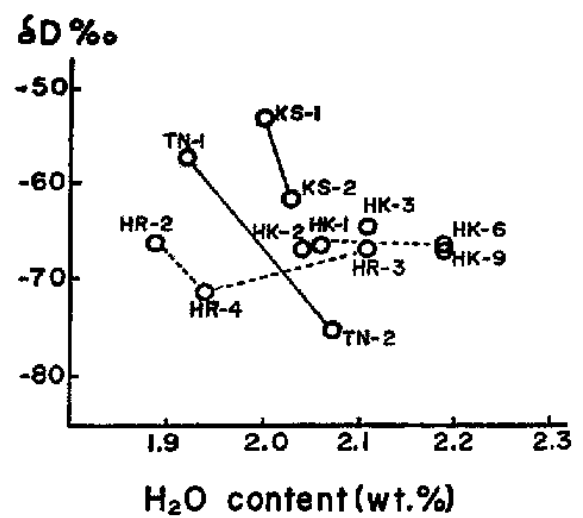

Fig. 4. Relationship between $\delta \mathrm{D}$ and $\mathrm{H}_{3} \mathrm{O}$ content of hornblende of the grantic rocks in the Kitakami mountains.

$\delta \mathrm{D}$ values are normalized to $\mathrm{Fe} /(\mathrm{Fe}+\mathrm{Mg})=0.40$. kabe mass. However, these samples may not be the product of magmatic differentiation but are the inclusions, which were influenced physically and chemically by the host granite.

As seen in Figs. 3 and 4, there is an inverse relationship between $\delta \mathrm{D}$ and water content of biotite and homblende in the individual mass, Kesengawa, Tôno and Hirota, i.e., the higher the content of water, the lower the value of $8 \mathrm{D}$ is. On the other hand, such relationship is not seen in the Hitokabe mass. This may have some connection to the fact that the range of water content of both biotite and hornolende of Hitokabe mass is narrower than those of the other three.

As seen in Fig. 5, the tie-lines of biotite and homblende of the Hiji and the Minakata masses from the Ryôke metamorphic belt exhibit a quite different inclination from those of four masses in the Kita-

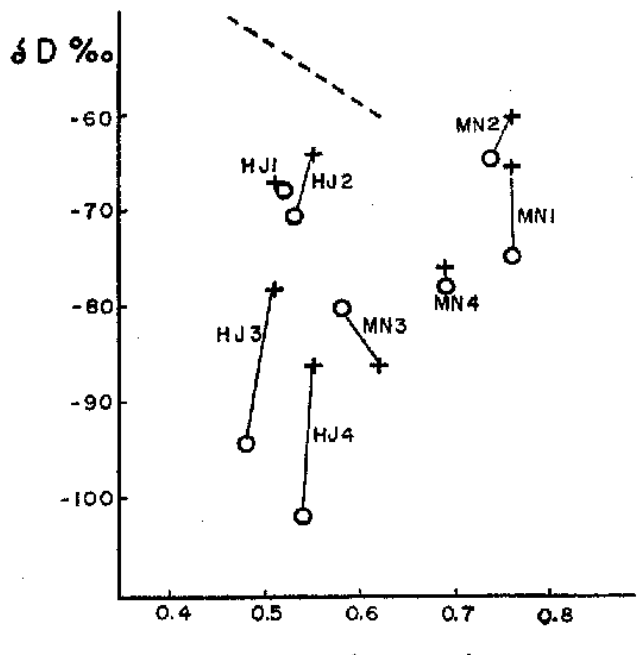

$\mathrm{Fe} /(\mathrm{Fe}+\mathrm{Mg})$

Fig. 5. Relationship bctween $8 \mathrm{D}$ and $\mathrm{Fe} /(\mathrm{Fe}+\mathrm{Mg})$ of biotite and hornblende of the granitic masses in the Ryoke metamorphic belt. Notation in the figure is the same to that in Table 1 


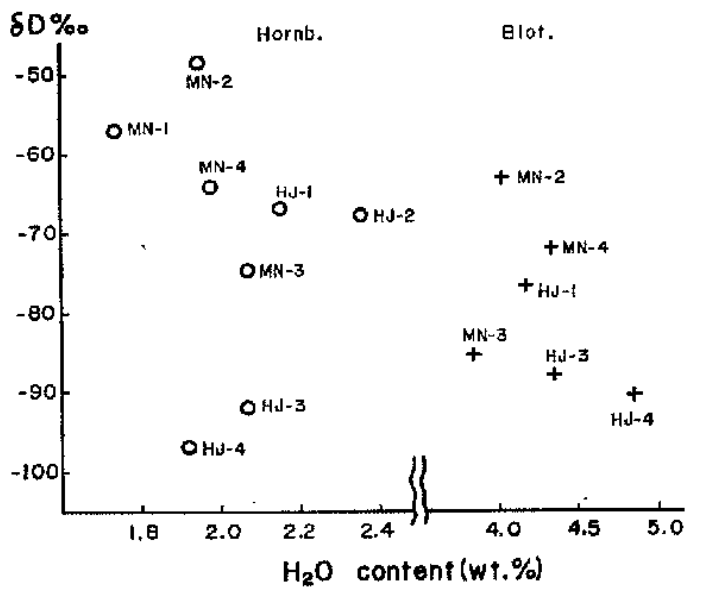

Fig. 6. Relationship between $\delta \mathrm{D}$ and $\mathrm{H}_{2} \mathrm{O}$ content of biotite and hornblende of the granitic rocks in Ryôke.

$\delta \mathrm{D}$ values are normalized to $\mathrm{Fe} /(\mathrm{Fe}+\mathrm{Mg})=\mathbf{0 . 5 0}$ HJ-2 and MN-1 are excluded because of the contamination of chlorite.

kami mountains shown in Fig. 2. The tielines are almost perpendicular to the "equilibrium line," i.e., $\delta \mathrm{D}$ of biotite is mostly higher than that of homblende. However, there are some exceptions. The tie-lines of $\mathrm{MN}-3$ and $\mathrm{HJ}-1$ show nearly equilibrated conditions as those of the pairs already found in the Kitakami mountains. The biotite-homblende pairs with perpendicular tie-line apparently represent disequilibrium situation with respect to the deuterium exchange. Moreover, the relationship between $8 \mathrm{D}$ and $\mathrm{SiO}_{2}$ content of the host rack is rather reversed when compared with that of the Kitakami mountains.

As seen in Fig. 6, there seems to be no conspicuous relationship between $\delta \mathrm{D}$ and water content of biotite and homblende, in contrast to the relationship found in the masses of Kitakami.

\section{Discussion}

According to Suzuoki and Epstein (1970), (1972), the fractionation factor, $\alpha=$
$(\mathrm{D} / \mathrm{H})_{\operatorname{mineral}} /(\mathrm{D} / \mathrm{H})_{\text {water }}=\left(1000+\delta \mathrm{D}_{\mathbf{M}}\right) /(1000$ $\left.+\delta D_{w}\right)$, of both biotite and hornblende can be represented by a linear combination of the temperature and chemistry dependent terms as,

$$
\begin{array}{r}
10^{3} \ln \alpha_{\mathrm{M}-\mathrm{W}}=-22.4 \times 10^{8} \mathrm{~T}-2+28.2 \\
+\left(2 \mathrm{X}_{\mathrm{A} 1}-4 \mathrm{X}_{\mathrm{Mg}}-68 \mathrm{X}_{\mathrm{Fo}}\right) \cdots(1)
\end{array}
$$

where $T$ denotes the absolute temperature and $\mathrm{X}$ the mole fraction of the six-coordinated cations. The left-hand side of eq. (1) can be approximated to $\delta \mathrm{D}_{\mathrm{M}^{-}} \delta \mathrm{D}_{\mathrm{w}}$ where the suffices $M$ and $W$ represent mineral and water respectively. When the amount of the mineral is negligible to the amount of water in an equilibrium mixture, $\delta \mathrm{D}_{\mathrm{w}}$ is virtually invariant and $\delta \mathrm{D}_{\mathrm{M}}$ only is subjected to a change with the change in chemical composition of the mineral even under the same temperature. Biotite and hornblende can be regarded as the "same" hydrous mineral with different chemical composition.

The inclination of the broken line shown in Fig. 2 gives the chemistry dependence of $\delta \mathrm{D}_{M}$ when the presence of six-coordinated aluminium is negligible. Since $\mathrm{X}_{\mathrm{A} \text { ) }}$ of most of the samples in this study is small (refer to Table 1), the contribution of $\mathrm{X}_{\mathrm{A} 1}$ term can be safely neglected. When a biotitehormblende pair can be regarded as being in equilibrium, e.g. Kitakami masses in this study, $\delta \mathrm{D}$ value at $\mathrm{X}_{\mathrm{F}_{\theta}}=0$ can be obtained by the extrapolation using the same inclination as that of the broken line in Fig. 2. Then Eq. (1) is simplified to

$$
\delta \mathrm{D}_{\mathrm{M}}{ }^{*}-\delta \mathrm{D}_{\mathrm{W}} \leftrightharpoons-22.4 \times 10^{6} \mathrm{~T}^{-2}+24.2
$$

where $\delta \mathrm{D}_{\mathrm{M}}{ }^{*}$ denotes the normalized $\delta \mathrm{D}$ value of the mineral.

On the basis of the results obtained for biotite-hornblende pairs from masses in the. Kitakami mountains, a following consideration is made using $\mathrm{Eq}(2)$. If the $\delta \mathrm{D}$ value 
of the coexisting water in Kitakami mountains was the same throughout, the biotitehornblende pair of $\mathrm{TN}-2$ was regarded to be equilibrated under the lowest temperature as indicated in Fig. 2. Although the $8 \mathrm{D}$ value of biotite of TN-2 seems to be slightly lower than the equilibrium value, the biotite-hornblende pair is assumed to be crystallized or isotopically equilibrated with the water in magma in the temperature range from 450 to $550^{\circ} \mathrm{C}$. Judging from the texture under the microscope the rock of TN-2 is neither recrystallized nor of nonmagmatic origin. Then the temperature of $450-550^{\circ} \mathrm{C}$ may be taken to be the minimum temperature during the magmatic stage.

Provided that the temperature of TN-2 pair is set and $\delta \mathrm{D}$ of the water in magma is the same throughout the crystallization of magma, the equilibrium temperature of biotite-homblende pair of KS-1 (apparently the highest temperature pair) is estimated to be about $700-1,000^{\circ} \mathrm{C}$. Such a temperature value is also acceptable for the highest crystallization temperature of a granitic magma. The equilibrium temperature of the other pairs in Kitakami should lie in the range from $450-550^{\circ} \mathrm{C}$ to $700-1,000^{\circ} \mathrm{C}$. The change in $\mathrm{SiO}_{2}$ content is also conformable to the estimation.

The already mentioned inverse correlationship between $\delta \mathrm{D}$ and water content can be interpreted in terms of the temperature effect; viz., the water content of hydrous silicate increases when the temperature of equilibration is lowered.

If the above consideration is valid, $\delta \mathrm{D}$ of the water in the granitic magma would be about $-29 \sim-37 \%$ which is definitely higher than $-60 \sim-70 \%$ of the present local surface water in the Kitakami mountains. The high $8 \mathrm{D}$ value of the water in this granitic magma may be attributed either to the crustal water of which $\delta \mathrm{D}$ varies with region and depth, or to the contribution of "juvenile water" from the mantle.

On the other hand, most of the biotitehomblende pairs from the Hiji and Minakata masses in the Ryôke metamorphic belt, showed apparent disequilibrium situation with respect to the deuterium partition. At the present time, it is difficult to give any decisive interpretation consistent with both chemical and geological information for the apparent disequilibrium. A simple and premature interpretation is that the biotite in granitic masses of Ryôke might have been subjected to the exchange of deterium with the water of high $\delta \mathrm{D}$ value after their formation, while the exchange of deuterium between homblende and water might have taken place to a lesser extent after their formation.

\section{ACKNOWLEDGMENT}

We would like to express our gratitude to Drs. H. Kano and Y. Hayama for their kind discussions on the petrological problems for the granitic bodies investigated in this paper. A part of the expense of this study was defrayed by the Grant in Aid for Scientific Researches from the Ministry of Education of Japan.

\section{REFERENGES}

Bigeleisen, J., Perlman, M.L. and Prosser, H.C. (1952), Conversion of hydrogenic materials to hydrogen for isotope analysis. Anal. Chem., 24, 1356-1357.

Epstein, S. and Taylor, Jr., H.P. (1970), The concentration and isotopic composition of hydrogen, carbon and silicon in Apollo 11 lunar rocks and minerals. Proceeding Apollo 11 Lunar Science Conference, 12, 1085-1096.

Friedman, I. and Smith, R.L., (1958), The dluterium content of water in some volcanic, glasses. Geochim. Cosmochim. Acta, 15, 218- 
228.

Godfrey, J.D., (1962), The deuterium content of hydrous minerals from the east-central Sierra. Nevada and Yosemite National Park. Geochim. Cosmochim. Acta, 26, 1215-1245.

Hayase, I., (1967), Data of age determination by Rb-Sr method. Henseitai, 4, 23 (in Japanese).

Kanisawa, S., (1969), On the Hitokabe granodiorite mass, Kitakami mountainland. Jour. Japan. Assoc. Min. Peiv. Econ. Geol., 62, 275288.

Kanisawa, S., (1972), Coexisting biotites and hornblendes from some granitic rocks in southern Kitakami mountains. Jour. Japan. Assoc. Min. Petr. Econ. Geol., 67, 332-344.

Karakida, Y., Tomita, T., Gottfried, D., Stern, T. W. and Rose Jr., H.J., (1965), Lead-alpha ages of some granitic rocks from north Kyushu and Central Japan. Mem. Fac. Sci. Kyusinu Univ., Ser. D, 16, 249-263.

Kawano, Y. and Ueda, Y., (1965), K-A dating on the igneous rocks in Japan (II) --granitic rocks in Kitakami massif -. Jour. Japan. Assoc. min. Petr. Econ. Geol., 53, 143-154.

Lawrence, J.R., (1970), $\mathrm{O}^{18} / \mathrm{O}^{16}$ and $\mathrm{D} / \mathrm{H}$ ratios of soils, weathering zones, and clay deposits. $P h$. D. Thesis, California Institute of Technology.

Savin, S.M. and Epstein, S., (1970), The oxygen and hydrogen isotope geochemistry of clay minerals. Geochim. Cosmochim. Acta, 34, 2542.
Sheppard, S.M.F., Nielsen, R.L. and Taylor, Jr., H.P., (1969), Oxygen and hydrogen isotope ratios of clay minerals from porphyry copper deposits. Ecan. Geol., 64, 755-777.

Sheppard, S.M.F. and Epstein, S., (1970), D/H and $\mathrm{O}^{18} / \mathrm{O}^{16}$ ratios of minerals of possible mantle or lower crustal origin. Earth Planet. Sci. Letters, 9, 232-239.

Shieh, Y.N. and Taylor, Jr., H.P., (1969), Oxygen and hydrogen studies of contact metamorphism in the Santa Rosa range, Nevada and other areas. Contr. Mineral. Petrol., 20, 306356.

Suzuoki, T. and Epstein, S., (1970), Hydrogen isotope fractionation between OH-bearing silicate minerals and water. Publications of the Division of Geological and Planetary Sciences, California Institute of Technology, Contribution No. 1921 (in preprint form)*

Suzuoki, T. and Epstein, S., (1972), Partition of hydrogen isotopes between hydrated silicate minerals and water. Chikyukagaku, 5, 38-44. (in Japanese).

Taylor, Jr., H.P, and Epstein, S., (1966), Deuterium-hydrogen ratios in coexisting minerals of metamorphic and igneous rocks (abstract). Trans. Amer. Geophys. Union, 47, 213.

* in printig in Geochim. Cosmochim. Acta (1974).

\section{若干の花湔岩体中の共存する黒雲母と角閂石の水素同位体}

\section{黒田吉益・鈴置哲朗・松尾禎士・蟹沢聡史}

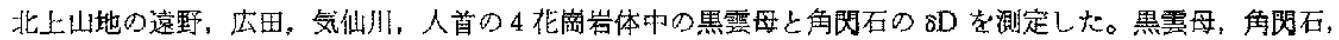

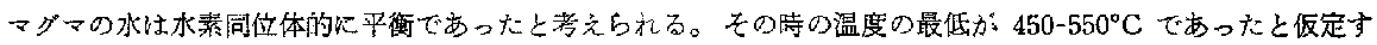
ると、最高の温度は $700-1000^{\circ} \mathrm{C}$ となり、、グ、の水の $\mathrm{D}$ は $-29 \sim-37 \%$ となる。高温と推定される花崫 岩はより端基性で，低温と推定されるるのは上り酸性である。

領家带の非持，南向両岩体のものについても同じ測定をしたが，これ北上山地の例とくらべてまったく異 なった結果を示し，黑雲母，角閃石，マダマの水俚水菜同位体的に非平衡であった。そのことの理由はよく分ら ないがこれらの花墑岩体の形成史が単純でかがたとを示するのであらら。 